\title{
O Rio de Janeiro e o Estado Nacional (1946-2010)*
}

\author{
Octavio Amorim Neto ${ }^{1}$ \\ Fabiano Santos ${ }^{2}$
}

${ }^{1}$ Escola Brasileira de Administração Pública e de Empresas (EBAPE), da Fundação Getulio Vargas, Rio de Janeiro, Brasil

${ }^{2}$ Instituto de Estudos Sociais e Políticos (IESP), da Universidade do Estado do Rio de Janeiro (UERJ), Rio de Janeiro, Brasil

$\mathrm{E}$ ste artigo procura mostrar que o estudo da trajetória política de um estado específico, no caso, o Rio de Janeiro, em uma república federativa, é também uma análise de como os contornos mais gerais da política estadual se relacionam com a configuração do quadro político-partidário em âmbito nacional. Portanto, para além de um estudo de uma unidade política subnacional, propomos, a seguir, parâmetros teóricos e empíricos para o avanço de pesquisas sobre o federalismo.

O que sugerimos não é exatamente uma novidade. Nas décadas de 1970 e 1980, cientistas sociais e historiadores, brasileiros e brazilianistas, procuraram analisar o peso político específico dos principais estados brasileiros no âmbito da Federação. Os mais destacados trabalhos dessa agenda de pesquisa foram as obras de Love (1971; 1980), Schwartzman (1982) e Wirth (1977). Não é surpresa terem sido Minas Gerais, São Paulo e o Rio Grande do Sul as unidades subnacionais por eles estudadas. Surpreende, todavia, a ausência de reflexão de monta sobre o Rio de Janeiro, tradicionalmente o segundo maior PIB e a terceira maior população do país. Conquanto não faltem publicações sobre as consequências políticas e econômicas da transferência da capital

\footnotetext{
* Os autores agradecem pelos dados econômicos e fiscais generosamente cedidos por José Roberto Afonso e Carlos Roberto Azzone, pelos comentários de Antônio Octávio Cintra e de dois pareceristas anônimos, e pela assistência de pesquisa de Saulo Said.
}

DADOS - Revista de Ciências Sociais, Rio de Janeiro, vol. 56, no-3, 2013, pp. 467 a 496. 
para Brasília em 1960 e da fusão do antigo Estado do Rio de Janeiro com a Guanabara em 1975 (ex.: Ferreira, 2000; Freire, Sarmento e Motta, 2001; Lessa, 2000; Motta, 2001; Osório, 2005), estas tratam sobretudo do impacto, por assim dizer, doméstico de tais mudanças. Assim, inexiste artigo ou livro que avalie sistematicamente a evolução do lugar do Rio de Janeiro na política nacional antes e depois da transferência e da fusão. Procuramos aqui suprir essa carência.

Do ponto de vista empírico, examinamos evidências quantitativas da frequência de políticos cariocas e fluminenses no Executivo Federal entre 1946 e 2010. Metodologicamente, tratamos a antiga capital, o velho Estado do Rio de Janeiro e o extinto Estado da Guanabara como uma unidade entre 1946 e 1974. A partir de 1975, essas três unidades se encontram dentro do novo Estado do Rio de Janeiro. Dessa maneira, oferecemos novas verificações empíricas a respeito do papel do Rio na política nacional e avançamos duas hipóteses: uma de natureza indutiva e histórica e a outra de cunho mais dedutivo e institucional, ambas extraídas da literatura sobre instituições políticas brasileiras e de nossas intuições a respeito do que tem acontecido na política desse estado nos últimos anos. A primeira argumenta que a participação de políticos do Rio nos gabinetes presidenciais é, em boa medida, uma função do peso relativo do estado nas bancadas de deputados federais dos principais partidos governativos. A segunda sustenta que o fortalecimento do governo central, a partir da promulgação da Constituição de 1988, no que toca ao seu relacionamento com os estados, forçou o Rio a ajustar-se às alianças partidárias montadas pelos presidentes, o que contribuiu para uma relativa recuperação da influência nacional do estado na primeira década do século XXI.

Dito isso, o artigo se organiza da seguinte maneira: a próxima seção apresenta uma medida quantitativa da variação do papel político do Rio de Janeiro na política nacional entre 1946 e 2010, com foco na participação ministerial dos estados; a terceira seção busca identificar as razões do impressionante declínio político do Rio entre o final da década de 1960 e o começo do atual século; a seção seguinte discorre sobre a recuperação política esboçada a partir de 2003; a quinta oferece uma reflexão de cunho normativo sobre as consequências, para o Brasil, do marcante declínio político e econômico do estado no plano nacional; a sexta seção enuncia as conclusões. 


\section{A PARTICIPAÇÃO DO RIO DE JANEIRO NOS GOVERNOS FEDERAIS}

Até recentemente, foram muito frequentes as notícias sobre a fuga de empresas e o esvaziamento econômico do Estado do Rio de Janeiro. Por exemplo, dados do Instituto Brasileiro de Geografia e Estatística (IBGE) mostraram que o Rio foi a unidade da Federação que menos crescera entre 1985 e 2001. Além disso, entre 1985 e 2002, o Rio de Janeiro também fora quase sempre mal no tocante à sua influência sobre a política nacional. Mesmo com a chegada de Lula ao poder em 2003, um presidente que recebera uma enorme percentagem dos votos dos eleitores cariocas e fluminenses no segundo turno da eleição de 2002 (79,0\%, a maior percentagem obtida por Lula numa contagem por estado), parecia que os políticos do Rio de Janeiro podiam ser facilmente descartados. Assim, em janeiro de 2004, os três ministros do Rio que Lula nomeara no dia da sua posse - Benedita da Silva, Miro Teixeira e Roberto Amaral - tiveram que deixar suas pastas ou foram afastados do governo. De janeiro de 2004 a julho de 2005, o estado ocupou apenas um cargo com status ministerial, a Secretaria de Direitos da Mulher.

Entretanto, e de forma não menos surpreendente, sob os dois mandatos de Lula, entre 2003 e 2010, o Rio de Janeiro alcançou seu nível mais alto de participação desde que o Brasil se redemocratizara em 1985, ficando, em média, com 6,9\% das nomeações ministeriais dos dois quadriênios.

Para se ter uma perspectiva histórica do peso político do Rio de Janeiro na política nacional, convém tabular alguns números a respeito da participação dos maiores estados nos gabinetes presidenciais durante os três regimes que tivemos desde o fim da Segunda Guerra Mundial: o regime democrático de 1946 a 1964, o regime militar de 1964 a 1985, e o novo regime democrático de 1985 ao presente. Cabe ainda lembrar que, no contexto do nosso presidencialismo de coalizão, as nomeações ministeriais constituem o principal mecanismo pelo qual os presidentes montam sua base de a poio político e, consequentemente, o controle de cargos ministeriais é um dos mais importantes meios de exercício de influência política no plano nacional (Abranches, 1988).

Para estimar o peso dos estados nos gabinetes presidenciais, é preciso definir critérios que estipulem quando a origem estadual de um ministro é relevante ou irrelevante para a sua nomeação. Por exemplo, o fato de Pedro Malan ter nascido e vivido no Rio de Janeiro não teve influência na sua escolha como ministro da Fazenda de FHC. Já a nomeação de 
Guido Mantega para essa pasta por Lula pode ser associada, entre outras dimensões, ao fato de ser um economista paulista. Além disso, há que se levar em conta não o lugar de nascimento dos ministros, mas o estado em que conduziram suas carreiras políticas. Assim, Dilma Rousseff, ainda que tenha nascido em Minas, deve ser considerada uma representante do Rio Grande do Sul nos gabinetes de Lula, uma vez que foi neste estado que transcorreu a sua carreira política. Por último, ministros com perfil exclusivamente técnico não devem ter suas nomeações relacionadas a qualquer estado. É o caso do embaixador Celso Amorim, diplomata de carreira, que foi o chanceler de Lula durante oito anos, mas cuja nomeação não esteve ligada à sua origem santista.

Portanto, a diferença entre tecnocratas e políticos é fundamental para os propósitos deste artigo ${ }^{1}$. Sem dúvida, aqueles também são atores políticos. Não obstante, seus recursos, preferências e critérios de desempenho são marcadamente diferentes dos que regem a ação de um político, mormente se este for detentor de cargo eletivo. Para um político, a defesa e a promoção dos interesses distributivos de partidos, classes sociais, grupos de interesse e regiões são inevitavelmente o foco da representação. Já os tecnocratas tendem a privilegiar critérios de eficiência e equidade alocativas com base em conhecimento especializado ou experiência profissional (Centeno e Silva, 1998). Porém, há também os tecnocratas cuja origem estadual é relevante, pois são nomeados justamente para levar em conta o impacto de suas decisões em âmbitos políticos subnacionais. Isso é inevitável num país de vasta dimensão territorial e numa federação heterogênea como a brasileira.

Outra decisão operacional de monta deste artigo é inserir, na mesma amostra, governos democráticos (os formados em 1946-1964 e 1985-2010) e autoritários (1964-1985). Contudo, se nossa distinção fundamental é entre ministros políticos e tecnocráticos, a comparação não deveria então cingir-se apenas aos regimes democráticos, já que, por definição, os regimes autoritários não precisam do apoio de políticos eleitos?

A favor da comparação de todos os governos do período 1946-2010, podem ser arrolados os seguintes fatores. Em primeiro lugar, não obstante o regime militar, ao longo desses 65 anos, as bases constitucionais do país permaneceram praticamente inalteradas: o presidencialismo (com a exceção do interregno parlamentarista de setembro de 1961 a ja- 
neiro de 1963), o bicameralismo, o federalismo, e o calendário e os sistemas eleitorais da Câmara dos Deputados, do Senado e das Assembleias Legislativas estaduais. Sem dúvida, durante essas seis décadas e meia, houve considerável variação no formato dos sistemas partidários, na extensão de poder do governo central vis-à-vis os governos subnacionais, na competitividade e lisura das eleições, e na independência e influência dos Poderes Legislativo e Judiciário. Entretanto - e aqui entra o segundo fator -, a necessidade de o Executivo federal contar com o apoio da classe política - seja no Congresso, seja nos estados esteve sempre presente, com a possível exceção dos 10 meses em que o Congresso esteve fechado em 1969. Ou seja, houve grande continuidade institucional e nas práticas políticas, o que permite o cotejamento entre os regimes democráticos e o autoritário. Obviamente, em geral, os políticos foram menos importantes em 1964-1985 do que em 1946-1964 e 1985-2010. Em particular, interessa-nos saber como o Rio de Janeiro foi afetado pela degradação da classe política promovida pelos militares.

Estabelecidos os critérios de avaliação do controle ministerial pelos estados e lançadas as bases de comparação entre os três regimes, olhemos a Tabela 1 a seguir. Nela exibe-se a percentagem de nomeações ministeriais (para cargos civis) destinadas ao Rio e a outros seis grandes estados, por regime. O dado mais impressionante é o declínio da participação ministerial do Rio de Janeiro. Em 1946-1964, o ex-Distrito Federal e os antigos estados do Rio de Janeiro e da Guanabara ficaram com 15,7\% das nomeações ministeriais, abaixo apenas de São Paulo, com 20,7\%. Sob o regime militar, o antigo Estado do Rio de Janeiro e o então recente Estado da Guanabara (até 1974) e o novo Estado do Rio de Janeiro (a partir de 1975) receberam uma percentagem consideravelmente menor de nomeações ministeriais, 5,3\%. No período de 1985 a 2010, o peso médio do Rio nos gabinetes presidenciais caiu novamente, para $4,6 \%$, muito próximo ao nível do Paraná $(4,0 \%)$ e de Pernambuco $(3,9 \%)$.

Cabe registrar que outros grandes estados também perderam influência política no plano federal de um período para outro. São Paulo, por exemplo, experimentou uma queda vertiginosa durante o regime militar. Porém, sob o atual regime democrático, voltou a ter um nível de participação nos gabinetes presidenciais próximo ao que tivera em 1946-1964. Note-se também que todos os sete estados decaíram politicamente sob o interregno autoritário. Isso era de se esperar, dado o for- 
Tabela 1

Média e Desvio-Padrão da Participação Ministerial dos Sete Maiores Estados, por Regime Político (1946-2010)

\begin{tabular}{|c|c|c|c|c|c|c|}
\hline \multirow[b]{2}{*}{ BA } & \multicolumn{2}{|c|}{$\begin{array}{c}\text { 1946-64 } \\
\text { Média Desvio-Padrão }\end{array}$} & \multicolumn{2}{|c|}{$\begin{array}{c}\text { 1964-85 } \\
\text { Média Desvio-Padrão }\end{array}$} & \multicolumn{2}{|c|}{$\begin{array}{c}1985-2010 \\
\text { Média Desvio-Padrão }\end{array}$} \\
\hline & 9,3 & 7,2 & 3,2 & 3,5 & 6,2 & 3,1 \\
\hline MG & 14,3 & 6,2 & 6,3 & 5,2 & 11,3 & 5,8 \\
\hline PE & 8,6 & 2,1 & 2,1 & 3,0 & 3,8 & 2,3 \\
\hline PR & 2,9 & 4,7 & 2,1 & 2,8 & 4,0 & 3,6 \\
\hline$R J^{*}$ & 15,7 & 8,0 & 5,3 & 4,8 & 4,6 & 2,4 \\
\hline RS & 7,9 & 5,2 & 7,4 & 5,1 & 7,8 & 3,4 \\
\hline SP & 20,7 & 3,4 & 2,1 & 2,7 & 18,2 & 6,5 \\
\hline Outros Estados & 9,3 & 7,7 & 6,3 & 5,1 & 27,6 & 7,4 \\
\hline $\mathrm{OEPI}^{* *}$ & 11,4 & 24,6 & 65,3 & 11,1 & 16,6 & 5,1 \\
\hline
\end{tabular}

Fontes: Para 1946-1964, Amorim Neto (1991); para 1946-1985, Abreu et al (2001); para 1985-2006, Amorim Neto (2007); e para 2007-2010, os dados foram coletados do portal da Presidência da República: http://www.biblioteca.presidencia.gov.br/ex-presidentes (acesso em outubro de 2011; do portal do Dicionário Histórico-Biográfico Brasileiro, do CPDOC/FGV: http://cpdoc.fgv.br/acervo/dhbb (acesso em outubro de 2011); e da Wikipedia: http:/ / pt.wikipedia.org (acesso em outubro de 2011).

* A sigla RJ engloba o antigo DF e o antigo Estado do Rio de Janeiro entre 1946 e 1960; engloba o antigo Estado da Guanabara e o antigo Estado do Rio de Janeiro entre 1960 e 1974; e, a partir de 1975, significa o novo Estado do Rio de Janeiro.

** Origem estadual politicamente irrelevante.

te caráter tecnocrático do regime e a aversão dos militares à política partidária. Não à toa, a percentagem de ministros cuja origem estadual foi politicamente irrelevante chegou a 65,3\% entre 1964 e 1985 (havia sido de 11,4\% em 1946-1964, vindo a ser 6,6\% em 1985-2010). Já o Rio Grande do Sul manteve aproximadamente a mesma cota de nomeações ministeriais ao longo dos três regimes. Mas apenas o Rio caiu ao longo dos três períodos, sendo também o estado que sofreu a mais drástica redução em sua presença nos gabinetes presidenciais entre a primeira experiência democrática e a atual.

Até o momento, os dados foram examinados de um ponto de vista bastante agregado. Se os desagregamos por presidência, um quadro mais complexo se apresenta, permitindo identificar a gênese e a motivação do declínio. Os Gráficos 1 e 2 a seguir descrevem, respectivamente, a percentagem de ministros do Rio de Janeiro em relação ao total de ministros, por presidência, e a percentagem de ministros deste estado em relação ao conjunto de ministros com origem estadual politicamente relevante, também por presidência. Os dois gráficos atestam que, entre 1946 e 1964, o estado teve presença política marcante nos governos de Dutra, 


\section{Gráfico 1}

Percentagem de Ministros do Rio de Janeiro em relação ao Total de Ministros, por Presidência (1946-2010)*

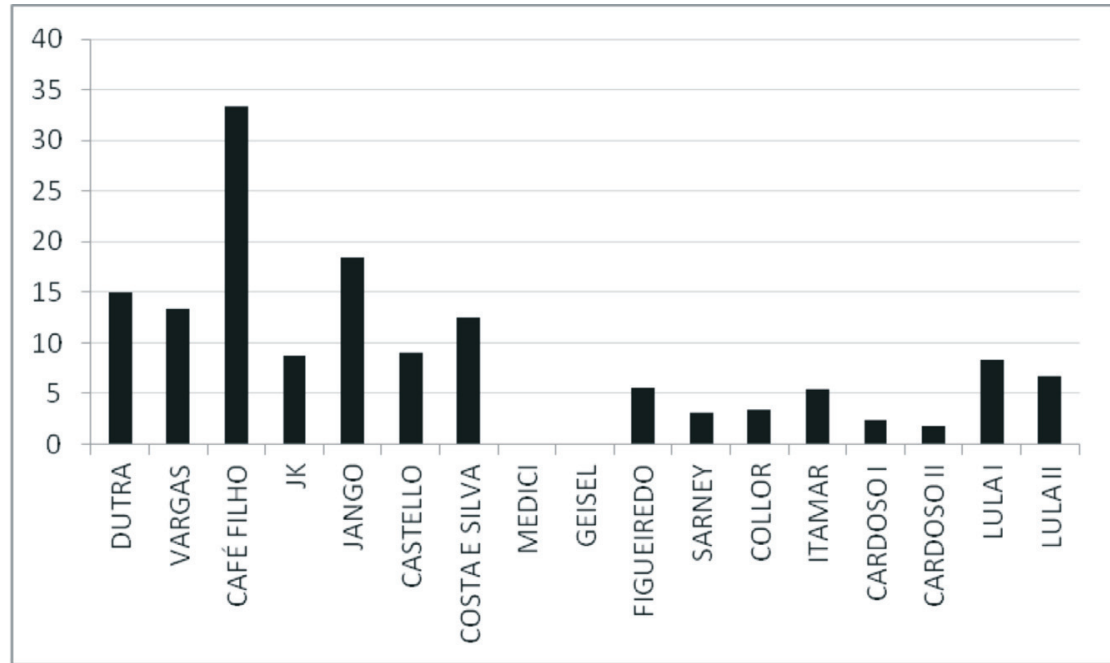

Fontes: As mesmas da Tabela 1

* Rio de Janeiro engloba o antigo DF e o antigo Estado do Rio de Janeiro entre 1946 e 1960; engloba o antigo Estado da Guanabara e o antigo Estado do Rio de Janeiro entre 1960 e 1974; e, a partir de 1975, significa o novo Estado do Rio de Janeiro.

\section{Gráfico 2}

Percentagem de Ministros do Rio de Janeiro em relação ao Total de Ministros com Origem Estadual Politicamente Relevante, por Presidência (1946-2010)*

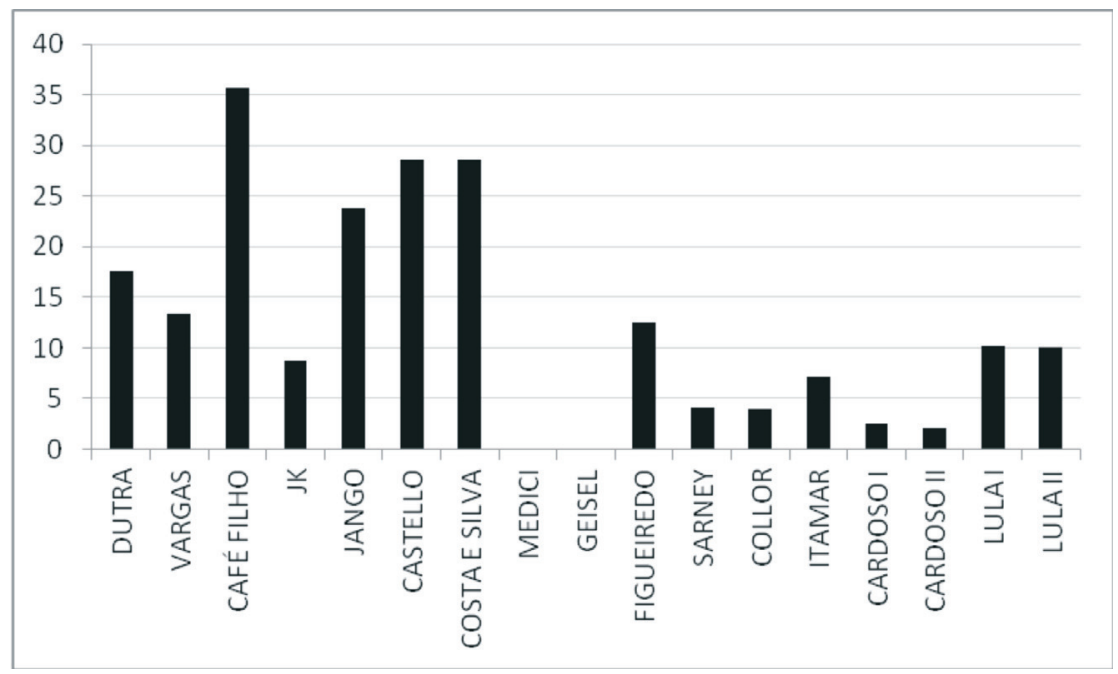

Fontes: As mesmas da Tabela 1.

* Rio de Janeiro engloba o antigo DF e o antigo Estado do Rio de Janeiro entre 1946 e 1960; engloba o antigo estado da Guanabara e o antigo estado do Rio de Janeiro entre 1960 e 1974; e, a partir de 1975, significa o novo estado do Rio de Janeiro.

DADOS - Revista de Ciências Sociais, Rio de Janeiro, vol. 56, n 3, 2013 
Café Filho e João Goulart e jamais medíocre nas outras administrações. Sob o regime militar, políticos cariocas e fluminenses se destacaram no governo de Costa Silva, mas não receberam, no que é a chave para nossa explicação, sequer um ministério de Médici e Geisel² .

Sob o regime democrático iniciado em 1985, o Rio de Janeiro passou a ser aquinhoado com uma fatia bastante reduzida dos gabinetes presidenciais de Sarney, Collor, FHC I e FHC II. A situação política do Rio de Janeiro melhorou de forma significativa nos dois mandatos de Lula, alcançando seus mais altos níveis de participação ministerial desde 1985 , principalmente quando se consideram apenas os ministros com origem estadual politicamente relevante.

Se considerarmos os dois terços de século coberto pelos Gráficos 1 e 2, fica claro que o ponto de inflexão que inaugura o declínio político do Rio de Janeiro foram as presidências de Médici e Geisel, pois, a partir desses 10 anos, nunca mais o Rio viria a ter uma cota do Executivo federal comparável aos picos que se observam entre 1946 e 1968. Ressalve-se, contudo, que a chegada da esquerda ao poder em 2003 sugere uma reversão do declínio.

\section{RAZÕES DO DECLÍNIO POLÍTICO DO RIO DE JANEIRO}

Quais são as razões para o marcante declínio político do Rio no plano federal, mormente entre 1969 e 2002, se o estado, desde 1946, permaneceu como o detentor do segundo PIB da Federação, da terceira maior bancada na Câmara dos Deputados, sendo também berço de algumas das melhores universidades e institutos de pesquisa do país?

Argumentamos que as razões do declínio político do Rio de Janeiro devem ser buscadas, acima de tudo, em fatores políticos. Descontando-se o fato obviamente relevante da transferência da capital para Brasília, as explicações que mais contribuem para o entendimento do fenômeno dizem respeito, por um lado, ao esforço - bem-sucedido - do regime militar de enfraquecer politicamente a rebelde ex-capital do país. E, por outro, sobretudo a partir de 1985, à dinâmica política do estado e às ambições eleitorais das suas lideranças.

No que toca ao colapso da presença de políticos cariocas e fluminenses nos governos Médici e Geisel, o que oferecemos aqui são reflexões que, futuramente, deverão ser objeto de pesquisa mais ampla. Assim, de acordo com Skidmore (1988:106), as nomeações ministeriais feitas por 
Médici tiveram um caráter mais marcadamente tecnocrático do que as dos seus dois antecessores militares. Além disso, a Assembleia Legislativa da Guanabara era dominada pelo MDB (Movimento Democrático Brasileiro), partido oficial de oposição ao regime. Embora o líder do MDB carioca, Chagas Freitas, não representasse uma ameaça ideológica aos militares, há que se destacar o fato de que o PTB (Partido Trabalhista Brasileiro), partido do presidente deposto pelas Forças Armadas em março de 1964, “[...] participou na constituição do MDB local [da Guanabara e do Rio de Janeiro] em proporções superiores à média nacional" (Dias, 2000:167-168). Ainda nas palavras de Dias (2000:168),

\begin{abstract}
Mesmo na fase mais fechada do regime, entre 1969 e 1973, o MDB manteria sua posição eleitoral, obtendo $50 \%$ dos votos da eleição para a Câmara Federal na Guanabara, na difícil eleição de novembro de 1970, valor bem superior à média nacional $(21,3 \%)$ e à votação obtida nos estados de São Paulo (16,4\%) e do Rio Grande do Sul $(36,4 \%)$. [...] estes valores seriam repetidos por ocasião da grande vitória no pleito nacional de 1974. O MDB obteve quase $60 \%$ dos votos na Guanabara, tornando o segundo estado da Federação em termos de importância econômica, com mais de dois milhões de eleitores, um bastião oposicionista incontornável.
\end{abstract}

Ou seja, o fato de a Guanabara estar nas mãos de um MDB com tais características certamente contribuiu para enfraquecer politicamente o Rio de Janeiro perante o Executivo federal. Além disso, não se pode esquecer que até o grande líder da direita carioca, Carlos Lacerda, bandeara-se para a oposição aos militares em 1966, consagrando o Rio como uma das grandes ameaças políticas ao regime autoritário.

O conflito do Rio de Janeiro com o regime militar continuou sob a presidência de Geisel. Não à toa, sob esse presidente, se deu a fusão dos estados da Guanabara e do Rio de Janeiro, fusão feita por meio da Lei Complementar no 20, de julho de 1974, apreciada em regime de urgência e aprovada em plenário em pouquíssimo tempo e com escassas emendas (Ferreira e Grynszpan, 2000:118). Convém deixar claro que não estamos a afirmar que a fusão tinha como objetivo exclusivo aniquilar politicamente o Rio de Janeiro. Entretanto, apesar de suas diversas motivações e complexa história ${ }^{3}$, é inegável que foi instrumental no amesquinhamento político dessa unidade da Federação. Novamente no dizer de Dias (2000:169), 


\begin{abstract}
Neste quadro de derrota eleitoral [do regime militar] e alternativa oposicionista, a fusão ofereceu para os estrategistas do regime militar, uma alternativa de baixo custo. Independentemente de suas justificações burocráticas ou dos projetos dos próceres da segurança nacional, o fato é o que processo da fusão representou, de imediato, a possibilidade de retirar esta independência do Estado da Guanabara e a nomeação discricionária de um novo governador. Ainda que o MDB continuasse como a força política dominante, uma vez que, no antigo Estado do Rio de Janeiro, o partido também havia vencido as eleições de novembro de 1974, adiava-se o problema da constituição do governo, com a nomeação do almirante Faria Lima.
\end{abstract}

À luz dos parágrafos anteriores, é, então, plausível sustentar que a fraqueza política do Rio de Janeiro no Executivo federal na década de 1970 correspondeu à força eleitoral, no estado, do MDB, nau capitânia da oposição. O quadro se agravou mais ainda com a fusão ocorrida em 1975 e após o restabelecimento do multipartidarismo em 1979. A Tabela 2 a seguir mostra o peso dos sete maiores estados dentro das delegações do MDB e da ARENA (Aliança Renovadora Nacional) na Câmara dos Deputados. Note-se que o Rio sempre teve a maior ou a segunda maior bancada dentro do MDB, posições que jamais ocupou dentro da ARENA.

Tabela 2

Peso dos Sete Maiores Estados (\%) na Delegação do MBD e da ARENA na Câmara dos Deputados (1966-1978)

\begin{tabular}{l|cc|cc|cc|cc}
\hline & \multicolumn{2}{|c|}{1966} & \multicolumn{2}{c|}{1970} & \multicolumn{2}{c|}{1974} & \multicolumn{2}{c}{1978} \\
UF & ARENA & MDB & ARENA & MDB & ARENA & MDB & ARENA & MDB \\
\hline BA & 9,0 & 4,5 & 8,4 & 3,2 & 11,0 & 2,9 & 10,4 & 4,1 \\
MG & 13,4 & 8,3 & 12,4 & 7,4 & 12,0 & 8,0 & 12,2 & 9,8 \\
PE & 6,9 & 3,8 & 5,3 & 3,2 & 6,8 & 2,9 & 6,1 & 4,1 \\
PR & 7,2 & 3,8 & 8,4 & 4,2 & 7,9 & 8,0 & 8,3 & 7,8 \\
RJ+GB & 5,8 & 19,7 & 8,0 & 21,1 & 7,9 & 10,9 & 4,8 & 18,1 \\
RS & 5,1 & 11,4 & 6,2 & 12,6 & 6,8 & 10,9 & 6,1 & 9,3 \\
SP & 11,6 & 20,5 & 14,2 & 11,6 & 8,9 & 16,7 & 7,8 & 19,2 \\
\hline Total & $\mathbf{2 7 7}$ & $\mathbf{1 3 2}$ & $\mathbf{2 2 5}$ & $\mathbf{9 5}$ & $\mathbf{1 9 1}$ & $\mathbf{1 7 4}$ & $\mathbf{2 3 0}$ & $\mathbf{1 9 3}$ \\
\hline
\end{tabular}

Fonte: Tribunal Superior Eleitoral, Candidatos Eleitos - Período 1945-1990, disponível em http://www.tse.jus.br/eleicoes/eleitos-1945-1990 (acesso em outubro de 2011).

Com a fusão, as forças políticas reunidas em torno da liderança de Chagas Freitas entraram em disputa pelo controle da máquina partidária 
em oposição aos seguidores de Amaral Peixoto, antigo líder do PSD (Partido Social Democrático) em território fluminense e que, no contexto bipartidário imposto pelos militares, passara a liderar o MDB local. Chagas finalmente derrotou Amaral Peixoto nas eleições indiretas para o governo do estado em 1978. No entanto, começou a enfrentar progressivo desgaste político, em larga medida devido às dificuldades de coordenação das elites políticas do antigo estado com os atores oriundos da antiga Guanabara. Para além dos efeitos da crise econômica que atingiu o conjunto do país no início da década de 1980 e que fortaleceu candidaturas de oposição em todos os estados, a derrota do candidato do PMDB (Partido do Movimento Democrático Brasileiro) ao cargo de governador do Rio nas eleições de 1982, Miro Teixeira, pode ser creditada também a um vigoroso processo de realinhamento político resultante da nova configuração territorial do estado.

De toda forma, com relação ao minúsculo peso político do Rio no Executivo federal entre 1985 e 2002, cabe registrar, em primeiro lugar, que o eleitorado do estado esteve sempre mais à esquerda do que as coalizões partidárias que dirigiram o governo nacional ao longo daqueles 18 anos. Tal quadro redundou em sérias divergências entre as duas entidades políticas.

Em segundo lugar, o principal partido a governar o Rio de Janeiro desde as primeiras eleições pluripartidárias em 1982, o PDT (Partido Democrático Trabalhista), sempre foi de médio a pequeno porte no plano nacional, o que contribuiu para reduzir a importância desta unidade federativa nas negociações relativas à formação de maiorias legislativas no Congresso. A Tabela 3 a seguir mostra o grande peso que o Rio de Janeiro possuiu na delegação dessa sigla na Câmara durante os vinte anos em que os partidos de esquerda estiveram na oposição ao governo federal (1983-2002).

Em terceiro lugar, os três grandes partidos que conduziram o governo nacional, de Sarney a FHC, o PSDB (Partido da Social Democracia Brasileira), o então PFL (Partido da Frente Libera) (hoje DEM - Democratas) e o PMDB, nunca tiveram um número expressivo de deputados e senadores fluminenses em suas bancadas (à exceção do PMDB a partir de 2006, tema a que voltaremos mais adiante). As Tabelas 4, 5 e 6 a seguir exibem, respectivamente, o peso dos sete maiores estados dentro das delegações do PSDB, PFL/DEM e PMDB na Câmara dos Deputados. São Paulo e Minas Gerais sempre controlaram as maiores banca- 
das dentro do PSDB, e Bahia e Pernambuco, dentro do PFL (a única exceção é 1998-2001, quando o RJ comandou a segunda maior bancada dentro do $\mathrm{PFL}^{4}$ ). Com relação ao PMDB, entre 1982 e 2002, o Rio de Janeiro sempre ficou apenas com a sexta ou sétima maior banca dentro da delegação do partido na Câmara (considerando-se apenas os sete maiores estados). Ou seja, a relativa fraqueza do Rio dentro das três agremiações que constituíram o núcleo partidário que lastreou politicamente a presidência entre 1985 e 2002 certamente debilitou a influência do estado no plano nacional.

\section{Tabela 3}

Peso dos Sete Maiores Estados (\%) na Delegação do PDT na Câmara dos Deputados (1982-2010)

\begin{tabular}{l|c|c|c|c|c|c|c|c}
\hline UF & $\mathbf{1 9 8 2}$ & $\mathbf{1 9 8 6}$ & $\mathbf{1 9 9 0}$ & $\mathbf{1 9 9 4}$ & $\mathbf{1 9 9 8}$ & $\mathbf{2 0 0 2}$ & $\mathbf{2 0 0 6}$ & $\mathbf{2 0 1 0}$ \\
\hline BA & 0,0 & 0,0 & 8,7 & 8,8 & 4,0 & 4,8 & 12,5 & 14,8 \\
MG & 0,0 & 4,2 & 0,0 & $\mathbf{2 3 , 5}$ & 4,0 & 4,8 & 8,3 & 7,4 \\
PE & 0,0 & 0,0 & 0,0 & 5,9 & 0,0 & 0,0 & 4,2 & 3,7 \\
PR & 0,0 & 4,2 & 4,3 & 8,8 & 4,0 & 4,8 & 4,2 & 0,0 \\
RJ & 69,6 & 54,2 & 41,3 & 23,5 & 28,0 & 33,3 & 12,5 & 11,1 \\
RS & 30,4 & 20,8 & 15,2 & 14,7 & 16,0 & 19,0 & 12,5 & 11,1 \\
SP & 0,0 & 8,3 & 4,3 & 5,9 & 16,0 & 19,0 & 12,5 & 11,1 \\
\hline Total & $\mathbf{2 3}$ & $\mathbf{2 4}$ & $\mathbf{4 6}$ & $\mathbf{3 4}$ & $\mathbf{2 5}$ & $\mathbf{2 1}$ & $\mathbf{2 4}$ & $\mathbf{2 7}$ \\
\hline
\end{tabular}

Fontes: Jairo Nicolau, Dados Eleitorais (1982-2006), disponível em http://jaironicolau.iesp.uerj.br/banco2004.html (acesso em outubro de 2011); e Tribunal Superior Eleitoral, Eleições Anteriores, disponível em http:/ / www.tse.jus.br/eleicoes/eleicoes-anteriores (acesso em outubro de 2011).

Tabela 4

Peso dos Sete Maiores Estados (\%) na Delegação do PSDB na Câmara dos Deputados (1990-2010)

\begin{tabular}{l|c|c|c|c|c|c}
\hline UF & $\mathbf{1 9 9 0}$ & $\mathbf{1 9 9 4}$ & $\mathbf{1 9 9 8}$ & $\mathbf{2 0 0 2}$ & $\mathbf{2 0 0 6}$ & $\mathbf{2 0 1 0}$ \\
\hline BA & 5,3 & 6,3 & 6,1 & 8,5 & 3,0 & 3,7 \\
MG & 23,7 & 12,7 & 14,1 & 19,7 & 10,6 & 14,8 \\
PE & 0,0 & 1,6 & 1,0 & 1,4 & 3,0 & 3,7 \\
PR & 10,5 & 1,6 & 5,1 & 7,0 & 6,1 & 5,6 \\
RJ & 2,6 & 9,5 & 11,1 & 15,5 & 4,5 & 3,7 \\
RS & 2,6 & 3,2 & 2,0 & 2,8 & 3,0 & 1,9 \\
SP & 23,7 & 23,8 & 15,2 & 21,1 & 27,3 & 24,1 \\
\hline Total & $\mathbf{3 8}$ & $\mathbf{6 3}$ & $\mathbf{9 9}$ & $\mathbf{7 1}$ & $\mathbf{6 6}$ & $\mathbf{5 4}$ \\
\hline
\end{tabular}

Fontes: As mesmas da Tabela 3. 


\section{Tabela 5}

Peso dos Sete Maiores Estados (\%) na Delegação do PFL/DEM na Câmara dos Deputados (1986-2010)

\begin{tabular}{l|c|c|c|c|c|c|c}
\hline UF & $\mathbf{1 9 8 6}$ & $\mathbf{1 9 9 0}$ & $\mathbf{1 9 9 4}$ & $\mathbf{1 9 9 8}$ & $\mathbf{2 0 0 2}$ & $\mathbf{2 0 0 6}$ & $\mathbf{2 0 1 0}$ \\
\hline BA & 11,9 & 13,3 & 18,0 & 19,0 & 23,8 & 20,0 & 14,0 \\
MG & 8,5 & 7,2 & 11,2 & 7,6 & 9,5 & 9,2 & 7,0 \\
PE & 9,3 & 13,3 & 12,4 & 7,6 & 9,5 & 4,6 & 4,7 \\
PR & 4,2 & 4,8 & 6,7 & 5,7 & 7,1 & 7,7 & 4,7 \\
RJ & 5,9 & 6,0 & 4,5 & 8,6 & 10,7 & 7,7 & 4,7 \\
RS & 1,7 & 1,2 & 1,1 & 1,0 & 1,2 & 3,1 & 2,3 \\
SP & 5,1 & 1,2 & 3,4 & 7,6 & 9,5 & 7,7 & 14,0 \\
\hline Total & $\mathbf{1 1 8}$ & $\mathbf{8 3}$ & $\mathbf{8 9}$ & $\mathbf{1 0 5}$ & $\mathbf{8 4}$ & $\mathbf{6 5}$ & $\mathbf{4 3}$ \\
\hline
\end{tabular}

Fontes: As mesmas da Tabela 3.

Tabela 6

Peso dos Sete Maiores Estados (\%) na Delegação do PMDB na Câmara dos Deputados (1982-2010)

\begin{tabular}{l|c|c|c|c|c|c|c|c}
\hline UF & $\mathbf{1 9 8 2}$ & $\mathbf{1 9 8 6}$ & $\mathbf{1 9 9 0}$ & $\mathbf{1 9 9 4}$ & $\mathbf{1 9 9 8}$ & $\mathbf{2 0 0 2}$ & $\mathbf{2 0 0 6}$ & $\mathbf{2 0 1 0}$ \\
\hline BA & 7,0 & 8,5 & 7,4 & 5,6 & 3,6 & 4,1 & 1,1 & 2,6 \\
MG & 13,5 & 13,5 & 13,0 & 10,3 & 10,8 & 12,2 & 7,9 & 9,0 \\
PE & 6,0 & 5,0 & 3,7 & 0,0 & 3,6 & 4,1 & 3,4 & 1,3 \\
PR & 10,0 & 9,2 & 6,5 & 3,7 & 4,8 & 5,4 & 9,0 & 7,7 \\
RJ & 5,0 & 5,0 & 1,9 & 3,7 & 2,4 & 2,7 & 11,2 & 10,3 \\
RS & 6,0 & 6,5 & 8,3 & 7,5 & 8,4 & 9,5 & 5,6 & 5,1 \\
SP & 15,0 & 10,8 & 11,1 & 13,1 & 6,0 & 6,8 & 3,4 & 1,3 \\
\hline Total & $\mathbf{2 0 0}$ & $\mathbf{2 6 0}$ & $\mathbf{1 0 8}$ & $\mathbf{1 0 7}$ & $\mathbf{8 3}$ & $\mathbf{7 4}$ & $\mathbf{8 9}$ & $\mathbf{7 8}$ \\
\hline
\end{tabular}

Fontes: As mesmas da Tabela 3.

Tabela 7

Peso dos Sete Maiores Estados (\%) na Delegação do PT na Câmara dos Deputados (1982-2010)

\begin{tabular}{l|c|c|c|c|c|c|c|c}
\hline UF & $\mathbf{1 9 8 2}$ & $\mathbf{1 9 8 6}$ & $\mathbf{1 9 9 0}$ & $\mathbf{1 9 9 4}$ & $\mathbf{1 9 9 8}$ & $\mathbf{2 0 0 2}$ & $\mathbf{2 0 0 6}$ & $\mathbf{2 0 1 0}$ \\
\hline BA & 0,0 & 0,0 & 5,7 & 4,1 & 8,6 & 5,5 & 9,6 & 12,0 \\
MG & 12,5 & 0,0 & 28,6 & 6,1 & 12,1 & 7,7 & 10,8 & 9,6 \\
PE & 0,0 & 0,0 & 0,0 & 4,1 & 1,7 & 1,1 & 6,0 & 4,8 \\
PR & 0,0 & 0,0 & 8,6 & 6,1 & 5,2 & 3,3 & 4,8 & 6,0 \\
RJ & 12,5 & 12,5 & 8,6 & 6,1 & 6,9 & 4,4 & 7,2 & 6,0 \\
RS & 0,0 & 12,5 & 11,4 & 14,3 & 13,8 & 8,8 & 8,4 & 9,6 \\
SP & 75,0 & 50,0 & 28,6 & 28,6 & 24,1 & 15,4 & 16,9 & 18,1 \\
\hline Total & $\mathbf{8}$ & $\mathbf{1 6}$ & $\mathbf{3 5}$ & $\mathbf{4 9}$ & $\mathbf{5 8}$ & $\mathbf{9 1}$ & $\mathbf{8 3}$ & $\mathbf{8 6}$ \\
\hline
\end{tabular}

Fontes: As mesmas da Tabela 3. 
De maneira complementar, os governadores do Rio, à exceção de Marcelo Alencar, sempre foram candidatos a presidente ou sérios presidenciáveis, o que, por sua vez, os colocou em rota de colisão frontal com o governo federal. Tudo isto num contexto de esvaziamento econômico do estado, o que contribuiu, em muito, para acirrar os ânimos de eleitores e líderes cariocas e fluminenses para com Brasília.

Cabe ainda um comentário a respeito de Marcelo Alencar, governador do Rio de Janeiro entre 1995 e 1998, isto é, sob o primeiro mandato de FHC. Os dois pertenciam ao mesmo partido, o PSDB. Assim, era de se esperar que o estado tivesse uma participação no gabinete presidencial maior do que a verificada (2\%). Por que isso não ocorreu? Uma possível razão já foi listada nos parágrafos anteriores: comparado ao de outros grandes estados, o peso do Rio dentro das delegações legislativas dos três maiores partidos governativos do período (PSDB, PFL e PMDB) era de segunda ordem. Além disso, pode ter sido também relevante o fato de FHC ter obtido relativamente poucos votos no estado $(47,2 \%)$. De fato, os piores percentuais estaduais de FHC em sua triunfal eleição em 1994 vieram do DF, RJ, SC e RS, sendo os três últimos justamente os estados em que o PDT de Leonel Brizola era forte. De qualquer modo, um estudo detalhado sobre as relações do Rio com o Executivo federal durante o primeiro mandato de FHC se faz necessário.

Em suma, nos 20 anos que se seguiram ao restabelecimento do pluripartidarismo em 1982, gerou-se uma espécie de ciclo vicioso nas relações entre o Rio de Janeiro e o governo federal: a distância política entre o estado e Brasília levou a um substancial declínio da presença do Rio nos gabinetes presidenciais, dificultando o entrosamento entre esta unidade da Federação e a capital federal, dificuldade que, no limite, levaria à queda nas transferências orçamentárias da União para o estado $^{5}$. Este resultado, por sua vez, acabou por justificar, em "bases objetivas", uma quase permanente disposição oposicionista no seio de eleitores e líderes cariocas fluminenses para com o governo federal, aumentando mais ainda a distância entre o Rio e Brasília.

\section{A RECUPERAÇÃO POLÍTICA DO ESTADO DO RIO DE JANEIRO}

Como se explica a recuperação política do Rio a partir de 2003? Entender a recuperação do prestígio e do peso político do estado no plano nacional exige uma pequena digressão histórica, especificamente, sobre o quadro político e partidário que antecedeu o golpe militar de 
1964. Lima Jr. et al. (1987) mostraram que a dinâmica do sistema partidário no âmbito nacional caminhava na direção da dinâmica do subsistema partidário estadual do Rio de Janeiro, naquele tempo representado pelo Estado da Guanabara.

O que significa dizer que a dinâmica de um sistema partidário caminha na mesma direção de um subsistema partidário? Foram duas as medidas usadas pelos autores para responder à questão: (1) a evolução do grau de dispersão eleitoral e parlamentar das forças partidárias na Câmara dos Deputados, em geral, e na Guanabara, em particular (enfatizando tanto a bancada estadual da GB na Câmara quanto a sua Assembleia Legislativa); e (2) a identificação dos partidos que, num e noutro caso, ascendiam e declinavam em termos eleitorais e de cadeiras legislativas.

O que mais chamou a atenção de Lima Jr. et al. quando observaram o quadro da disputa eleitoral e parlamentar na Câmara dos Deputados a partir das eleições de 1958 foram o avanço contínuo do PTB, em prejuízo do PSD, e a relativa estabilidade da UDN (União Democrática Nacional). Como resultante, identificaram um quadro de maior fragmentação eleitoral e partidária, e, como efeito da natureza da disputa entre as bases de apoio dos trabalhistas e as forças udenistas, também um quadro de radicalização e polarização ideológica. Ou seja, o centro perdia força, com as extremidades ampliando seu poder, em paralelo com o crescente enrijecimento das posições de bancadas e facções no interior dos partidos.

O traço que sempre marcou a disputa partidária na antiga capital, e que continuou a marcar o novo Estado da Guanabara, foi justamente o da polarização entre o PTB e a UDN. No Rio de Janeiro, o PSD nunca gozou de grande densidade eleitoral, sempre tendo que disputar espaço com uma miríade de pequenos partidos, alguns mais e outros nem um pouco relevantes. O que Lima Jr. et al. tentaram mostrar é que, às vésperas do golpe de 1964, a dispersão de forças políticas na Câmara dos Deputados, ou seja, no plano nacional, assim como a temperatura do jogo político neste mesmo plano, se aproximava cada vez mais daquilo que sempre caracterizara a política na antiga capital.

Como indicamos na segunda seção deste artigo, com o golpe militar, a ex-capital da República, sua polarização ideológica e sua influência sobre a política nacional tornaram-se alvos preferenciais de intervenção do novo regime autoritário. Depois de um início em que a presença 
de ministros oriundos do Rio de Janeiro ainda era sentida, observa-se um longo período durante o qual esta unidade da Federação perde relevância no cenário político nacional, sobretudo se medimos esta relevância como presença nos gabinetes presidenciais.

Vale lembrar o que dissemos no início do trabalho: o estudo da recuperação política do Rio é também um estudo de como os contornos mais gerais da política estadual se relacionam com a configuração do quadro político-partidário em âmbito nacional. Recapitular alguns pontos e aprofundar outros mais uma vez se faz necessário.

Com a extinção do PTB e a cassação ou exílio dos seus principais quadros, a esquerda política no Rio de Janeiro, composta, de uma parte, pelas camadas sociais de mais baixa renda e, de outra, por parcelas da classe média identificada ideologicamente com a esquerda intelectual, passou a votar no MDB. Já o voto "popular" acabou dominado pela máquina eleitoral e política comandada pelo ex-governador Chagas Freitas, dando origem ao fenômeno do chaguismo e passando o voto mais intelectualizado, digamos assim, a ser canalizado para políticos pertencentes à chamada ala "autêntica" do $\mathrm{MDB}^{6}$.

Como dito na seção anterior, a transição democrática e o restabelecimento do multipartidarismo tiveram impactos importantes na estruturação da disputa partidária no Rio. Leonel Brizola, herdeiro do antigo trabalhismo, reorganiza o velho PTB, agora sob uma nova sigla, PDT, em 1980. Vence as eleições para governador em 1982 e constitui uma importante bancada de deputados estaduais e federais. Durante um longo tempo, Brizola e seu partido constituíram a referência do voto de esquerda "popular" no Rio de Janeiro, assim como boa parte dos políticos que viria a dar o tom da competição política no estado ingressara na vida pública a reboque da sua liderança ${ }^{7}$.

Se o voto da esquerda, sobretudo o popular, foi canalizado, no Rio de Janeiro, para o PDT, o mesmo não ocorreu em âmbito nacional. Neste nível, a partir das bases estabelecidas em São Paulo, Minas Gerais e Rio Grande do Sul, é o PT (Partido dos Trabalhadores) a sigla que consegue a hegemonia de tal voto, tendência que se consolida após a derrota de Brizola para Lula nas eleições presidenciais de 1989 e o mal-sucedido segundo governo daquele no Rio em 1991-1994. A Tabela 7, acima, apresenta o peso dos sete maiores estados dentro da delegação do PT na Câmara dos Deputados, deixando clara a preponderância daquelas três unidades da Federação. 
Com a decadência do brizolismo, sobretudo como resultado de conflitos que se estabelecem entre antigas e novas facções e lideranças do PDT (cujo melhor exemplo é o ex-governador Anthony Garotinho), o voto popular no Rio se tornou, mais uma vez, objeto de disputa. Porém, o PT não logrou ampliar seu apoio eleitoral para além de alguns nichos bem demarcados por lideranças como Benedita da Silva, Carlos Minc e Jorge Bittar, lideranças cuja capacidade de agregar apoio não avançou para além do necessário para a conquista de cargos legislativos. No vácuo do brizolismo e da falta de pujança do PT local, surgiu a oportunidade para o velho PMDB recobrar a posição perdida para Leonel Brizola em 1982, como mostra a Tabela 6 acima, principalmente a partir de 2006 .

Nas eleições de 2006, no segundo turno, o senador peemedebista Sérgio Cabral obtém vitória contundente sobre a candidata do minúsculo PPS, a juíza Denise Frossard. O segredo do sucesso de Cabral residiu em boa parte na decisão de aliar-se, no âmbito nacional, ao candidato do PT à presidência, Lula, que também disputava o segundo turno. Os contornos da aliança que hoje domina a política carioca e a fluminense vieram então a se definir, contornos que invertem a trajetória percorrida a partir do fim da década de 1960 . Se, até meados dessa década, a política nacional "seguia" a política carioca, com sua marca de fragmentação e polarização ideológica, agora é a disputa local que se orienta segundo os ditames da política nacional.

Desde 2006, após a vitória de Sérgio Cabral na disputa pelo governo do estado, a coalizão entre o PMDB e o PT tem organizado a aliança entre setores populares, setores da classe média e elites econômicas alinhadas ao projeto defendido por Lula e sua sucessora, Dilma Rousseff. É pela via do alinhamento ao projeto hegemônico no plano nacional e da reprodução quase perfeita, no âmbito estadual, da coalizão partidária que sustenta o Executivo federal que o Rio de Janeiro conseguiu recuperar sua influência na política nacional. Temos aqui não apenas uma coincidência de siglas a comporem coalizões governativas, mas também uma aproximação de agendas, permitindo ao estado uma captura mais ampla de espaço político e transferências orçamentárias.

Em suma, nossa hipótese, de natureza indutiva e histórica, reza o seguinte: na década de 1950 e no começo da década de 1960, a política do Rio de Janeiro moldara, em considerável medida, a estrutura da competição partidária nacional e a composição dos gabinetes presiden- 
ciais. A década de 1960 viria a ser o último período em que o Rio de Janeiro teria grande influência sobre os rumos da política nacional, mesmo sob os governos militares de Castello Branco e Costa Silva. A década de 1970 assistiria à redução radical dessa influência.

Ironicamente, os vinte primeiros anos do novo regime democrático iniciado em 1985 confirmariam o declínio político do estado. Já na segunda metade da primeira década do século XXI, o Rio voltaria a ter um peso político nacional mais compatível com a sua condição de segundo PIB e terceira população da Federação. Porém, essa recuperação política expressou, sobretudo, o alinhamento das forças partidárias do estado à política do Executivo federal.

Assim, se durante o período 1946-1964 a influência política do Rio de Janeiro decorreu da capacidade de exportar seu padrão de competição partidária para o plano nacional, sob o atual regime representativo, o Rio recupera influência após decidir importar os padrões de alinhamento partidário estabelecidos pelo governo central.

Que condições permitiram ao Rio exportar sua política para o plano nacional na década de 1950 e que condições levaram o estado a ter que importar a política da presidência, no começo do século XXI, para que voltasse a ter um papel político nacional relevante? Aqui elaboramos a nossa segunda hipótese, de natureza institucionalista e dedutiva.

Em 1946-1964, com a exceção do interregno de Nereu Ramos, quatro das seis administrações presidenciais foram abortadas prematuramente. Entre outubro de 1988 e 2013, apenas uma das sete administrações federais não concluiu o seu mandato constitucional. Segundo esse simples critério de avaliação de desempenho político, o Brasil melhorou muito após a promulgação da Constituição de 1988. Segundo Figueiredo e Limongi (2007) e Santos (2003; 2007), há mecanismos institucionais que explicam a recente tendência a uma maior estabilidade: a concentração de prerrogativas legislativas nas mãos do chefe do Executivo promovida pela nova Carta Magna fortaleceu a efetividade governamental, o que, por sua vez, diminuiu a probabilidade de encerramento prematuro das presidências. Essas prerrogativas legislativas dizem respeito, sobretudo, às medidas provisórias, à urgência constitucional e aos poderes orçamentários.

Esses mesmos autores, todavia, reconhecem que o fortalecimento do Poder Executivo tem-se dado pari passu à diminuição do poder legife- 
rante do Congresso e dos legisladores tomados individualmente. Como se dá o enfraquecimento do Legislativo?

Em trabalho sobre o perfil dos deputados federais que conseguem ver aprovados seus projetos de lei, Amorim Neto e Santos (2003) sustentam que o Congresso brasileiro tem um papel de menor importância no elaboração das leis não só por causa da ampla delegação ao Executivo de autoridade para tomar decisões sobre políticas públicas de abrangência nacional (por meio de medidas provisórias), mas também em virtude dos incentivos à construção das carreiras legislativas. Esses incentivos decorrem do fato de ser o Poder Executivo o centro de gravidade política do país, dissuadindo os deputados de tentarem uma carreira mais duradoura no Congresso. Por sua vez, a existência de poucos políticos dispostos a permanecer muito tempo no Congresso limita ainda mais o papel do Legislativo na elaboração de políticas nacionais (Amorim Neto e Santos, 2003:692).

De maneira complementar, a Constituição de 1988 procurou descentralizar o poder político, numa resposta à concentração promovida pelo regime militar. A nova Carta Magna transferiu montante considerável de recursos fiscais para estados e municípios. Porém, o esforço de debelar a inflação acabou por chocar-se com o intuito descentralizador da Assembleia Nacional Constituinte. O fim da inflação alta em 1995 desvelou a crise fiscal dos estados. FHC os ajudou a sair dela exigindo em contrapartida a privatização de empresas e bancos, o que, por sua vez, ensejou um pujante processo de centralização (Arretche, 2012). Este tem como uma das suas principais expressões uma alta e crescente carga fiscal, extraída, em boa medida, por meio de contribuições tributárias que não têm que ser partilhadas pela União com estados e municípios. A Lei de Responsabilidade Fiscal, promulgada em 2000, é outro ponto de inflexão desse processo. Mas há nele uma grande novidade: pela primeira vez em nossa história, o Brasil experimentou um processo de centralização em bases democráticas, centralização a que Lula viria a dar continuidade, seja aumentando a carga fiscal, seja por meio de programas sociais como o Bolsa Família.

Para oferecer sólidas evidências do fortalecimento do governo federal ao longo das últimas décadas, o Gráfico 3 a seguir, elaborado a partir de dados cedidos pelo economista José Roberto Afonso, mostra a divisão da arrecadação direta (como percentagem do PIB) entre União, estados e municípios em 1970-2012. Está claro que, a partir do começo da 


\section{Gráfico 3}

Divisão Federativa da Arrecadação Direta

1970-2012 - \% PIB

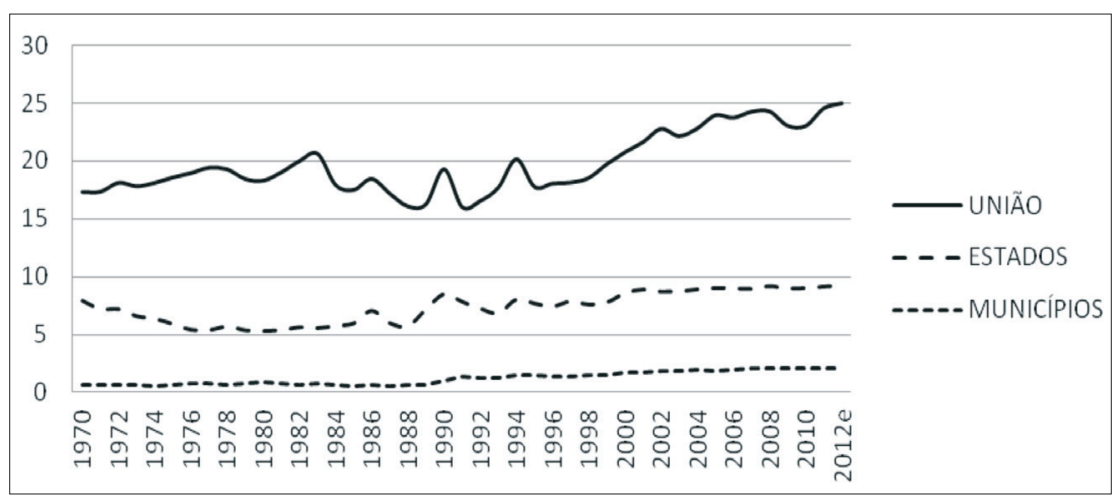

Fonte: Elaboração dos autores a partir de dados cedidos por José Roberto Afonso.

década de 1990, a União é a grande vencedora na disputa pela receita fiscal do país. A partir de 2000, a fatia dos estados se estabiliza e a dos municípios cresce um pouco ${ }^{8}$. Isto é, os estados, na última década, foram os perdedores no conflito federativo. Isso significou um forte incentivo fiscal para que se ajustassem politicamente ao Executivo federal.

A centralização significa essencialmente o fortalecimento do Poder Executivo nacional em detrimento dos demais entes federativos. Esse fortalecimento é maximizado pelo fato de alguns estados e metade dos municípios não conseguirem se sustentar exclusivamente com seus próprios meios fiscais. Portanto, no tocante às relações entre o governo central e os governos subnacionais, o Brasil tem vivido uma situação relativamente semelhante à identificada nas relações Executivo-Legislativo, sob a qual o fortalecimento do Poder Executivo corresponde ao enfraquecimento de outras importantes unidades políticas (no caso, os governos subnacionais).

A proposição subjacente à discussão entabulada nos últimos parágrafos pode ser formulada da seguinte maneira: a ampliação das prerrogativas da União gera incentivos para que os atores políticos estaduais se coordenem no sentido de emular em suas próprias unidades federativas o formato das coalizões políticas organizadas em âmbito nacional. O caso recente do Rio de Janeiro seria a manifestação empírica perfeita e acabada da validade da proposição. 
Por último, uma nota sobre as relações entre o declínio político e o declínio econômico do Rio de Janeiro se faz necessária. O Gráfico 4 a seguir, elaborado a partir de dados cedidos pelo economista Carlos Roberto Azzone, mostra a evolução do peso relativo das economias de Minas Gerais, Rio de Janeiro e São Paulo como percentagem do PIB nacional entre 1939 e 2010. É impressionante a decadência econômica do Rio. No começo da série, o estado chega a ter $20,7 \%$ do PIB nacional. Em 2010, este valor despenca para 10,8\%! Isto é, ao longo de dois terços de século, a presença econômica do Rio foi cortada pela metade. São Paulo também decaiu, mas não à taxa observada para o Rio: de um pico de 42,7\% em 1973 para 33,1\% em 2010. Minas Gerais se manteve relativamente estável ao longo dos 72 anos analisados. Por conta disso, o Rio, malgrado seu declínio, sempre se manteve como o segundo maior PIB estadual do país 9 .

De qualquer modo, o esvaziamento econômico por que passou o Rio, em tese, pode ser considerado um fator no declínio político da região, uma vez que dinamismo econômico e poder político costumam andar de mãos dadas. Um possível mecanismo que intermedeia a relação entre declínio econômico e declínio político é o enfraquecimento de presidenciáveis ou candidatos presidenciais que tenham sido governadores do estado. Como a perda de dinamismo econômico debilitara o desempenho administrativo dos governadores do Rio e, consequentemente, sua imagem perante o eleitorado nacional, suas postulações à presidência acabaram sempre fracassando. São os casos das candidaturas presidenciais de Brizola em 1989 e 1994 e de Garotinho em 2002. O fato de Wellington Moreira Franco, governador do Rio em 1987-1990, ter desistido de candidatar-se à presidência em 1989 pode ser também creditado à má imagem que deixara como administrador.

O Gráfico 4, porém, também deixa claro que o declínio econômico do Rio é um fenômeno que precede a transferência da capital para Brasília, período em que a influência política da região estava no seu auge. De maneira complementar, a recuperação política do Rio na primeira década do século XXI também se deu num contexto de perda de presença econômica nacional, ainda que a uma taxa mais suave do que a verificada nas décadas anteriores. Tais constatações reforçam uma das nossas principais proposições: a variação na influência política do Rio no plano nacional deve ser explicada por fatores predominantemente políticos. 


\section{Gráfico 4}

Participação de MG, RJ e SP no PIB Brasileiro

(1939-2010)

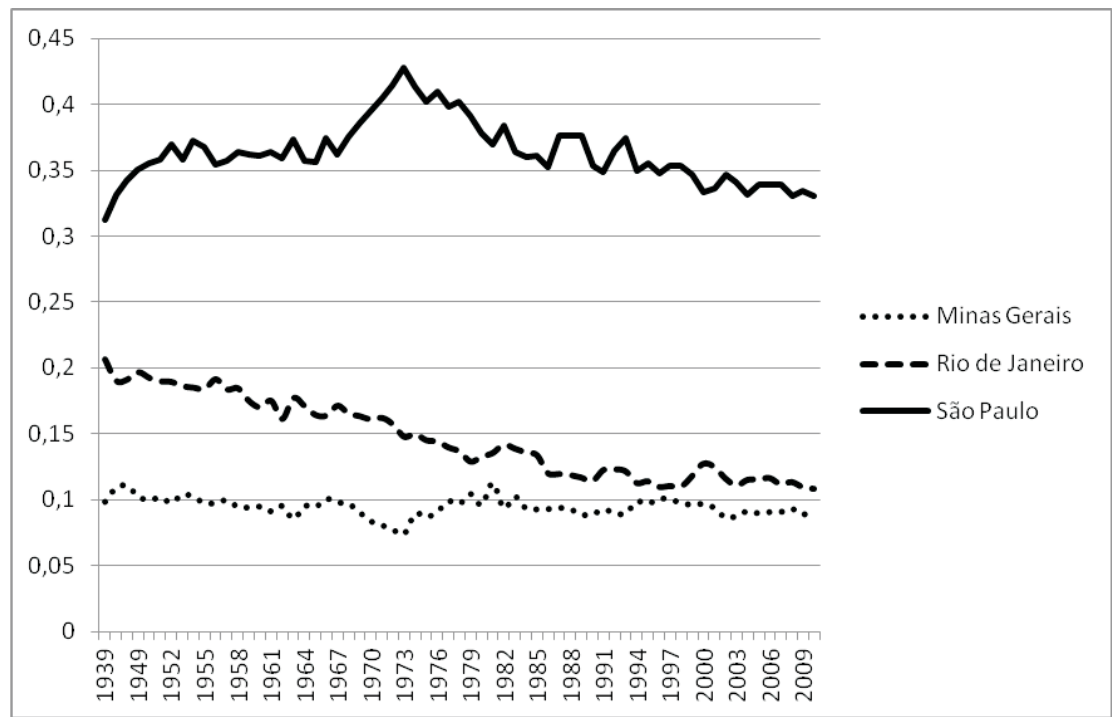

Fonte: Elaboração dos autores a partir de dados cedidos por Carlos Roberto Azzone.

\section{Foi bom para você? As Consequências do Declínio do Rio para o Brasil}

O pronunciado declínio político e econômico do Rio é um dos aspectos mais marcantes da história da Federação brasileira nos últimos cinquenta anos. Sabemos que isso foi péssimo para o estado. Mas o que significou para o país?

Para esboçar uma resposta, visitamos brevemente o trabalho clássico de Simon Schwartzman, Bases do Autoritarismo Brasileiro (publicado em 1982), uma reflexão sobre o desenvolvimento brasileiro marcada por uma discussão a respeito do papel dos principais estados. Segundo Schwartzman, a política brasileira passara, historicamente, pelo eixo Rio-Minas-Nordeste-Rio Grande do Sul, deixando de fora justamente o centro mais dinâmico da economia do país, São Paulo (e também Paraná e Santa Catarina), o qual, no máximo, produzira lideranças populistas, que não lograram transcender a fronteira do estado.

Seguindo Faoro (1958), Schwartzman vê o Estado Nacional brasileiro, até o final da década de 1970, como sendo essencialmente patrimonialista, no sentido de que não seria o "representante" de determinados 
interesses, mas, sim, o objeto de interesses de um estamento político que viveria de e para o poder; de que a política exercida por este Estado seria ou autoritária, com os militares, ou populista, com Vargas, ou uma combinação das duas coisas; e que o sistema partidário de 1946-1964 se basearia na cooptação das lideranças (inclusive sindicais) pela oligarquia política ${ }^{10}$.

Schwartzman esperava que, com o tempo e a modernização do país, outro tipo de política, originária de São Paulo, passaria a predominar no Brasil - uma política mais autenticamente representativa, com partidos apoiados nas classes modernas, burguesas e proletárias, da parte mais capitalista do país. Com o declínio histórico do Rio e a chegada ao poder federal do PT e do PSDB - partidos com tais atributos - a partir de meados da década de 1990, parte das expectativas de Schwartzman se cumpriu. De fato, nossos dados sobre a participação ministerial dos estados corroboram as teses e expectativas de Schwartzman: o regime militar foi duríssimo com os políticos paulistas, passando Minas e o Rio Grande do Sul a serem os estados com melhor participação ministerial. De 1985 a 2010, entretanto, São Paulo emerge como o estado dominante nos gabinetes presidenciais, capitaneado por líderes do PSDB e do PT, resultado que oferece margem à visão segundo a qual o programa de modernização da política brasileira previsto por Schwartzman estaria seguindo seu curso.

Uma leitura da história brasileira inspirada por Schwartzman, portanto, poderia levar a crer que o declínio do Rio teve um aspecto positivo para o Brasil, uma vez que significou o enfraquecimento de uma das principais bases estaduais do populismo. A nosso ver, o problema com tal interpretação é a fragilidade do conceito de populismo ${ }^{11}$ e a falta de precisão no que concerne ao significado essencial da queda de influência política nacional desta unidade da Federação.

Como procuramos mostrar na segunda seção deste artigo, o problema da política na antiga capital federal residia em seu caráter fragmentado e polarizado, aspecto que, aos poucos, passou a invadir a dinâmica do conflito político no âmbito nacional. Pelo lado conservador, a UDN não admitia soluções de compromisso por entender que a democracia representativa brasileira padecia de um vício de origem: varguista, corporativa, baseada na cooptação de segmentos populares desqualificados para o exercício da escolha política por meio do voto. Pelo lado do trabalhismo, os opositores seriam traidores da nação, entreguistas das riquezas naturais e do fruto do sacrifício do povo trabalhador. Por conseguinte, sim, a decadência do Rio significou, em alguma medida, 
a revalorização dos mecanismos de mediação da política representativa.

Há alguma coisa negativa para o país advinda do declínio do Rio? Cremos que sim, pois dificilmente pode ser boa para um país a dominância excessiva de uma de suas unidades constitutivas, como tem sido o caso de São Paulo sob o regime nascido em 1985. Os dezesseis anos seguidos em que o país foi governado por presidentes originários politicamente desse estado - isto é, os quatro mandatos de FHC e Lula - são um indicador eloquente de dominância. Se é verdade que ocorreu uma desconcentração de poder no plano regional gerada pela decadência carioca-fluminense, é também verdadeiro que temos assistido a uma tendência de concentração por conta do excessivo peso de políticos oriundos de São Paulo.

Por último, o amesquinhamento de uma unidade da Federação com o peso econômico e cultural da região em que se fez e consolidou a independência nacional acaba por produzir o risco de retomada de uma política de gueto, de isolamento e autovitimização vis-à-vis o resto do país, política deletéria para o Rio e para o Brasil em seu conjunto, pois em nada contribui para uma sólida convivência democrática entre as entidades federativas.

\section{CONCLUSÃO}

Este artigo procurou mostrar que, entre 1946 e 1964, uma unidade subnacional importante como o Rio de Janeiro logrou exportar sua política para o plano nacional porque a balança de poder entre o governo central, por um lado, e o Congresso e a Federação, por outro, pendia para estes. Durante o regime autoritário, o Executivo, como era de se esperar, concentrou amplas prerrogativas, passando a ter recursos para punir o Rio por sua rebeldia. Com a vida ancorada nesta unidade federativa, apenas técnicos com origem estadual politicamente irrelevante viriam a participar dos gabinetes presidenciais entre 1969 e 1979.

A diferença entre tecnocratas e políticos é de extrema importância para nossa discussão. Certamente, os primeiros também podem ser considerados atores políticos. Todavia, sua agenda, interesses e medidas de sucesso são distintos dos parâmetros que marcam a atuação de um político, sobretudo se eleito por determinada região e estado. Em uma república federativa como a brasileira, pressões pela defesa dos interesses distributivos de municípios e do estado são fatos corriqueiros, necessários e inarredáveis na vida de um representante. Os tecnocratas, 
por sua vez, sobretudo aqueles cuja origem estadual é politicamente irrelevante para sua nomeação para um ministério, observam indicadores relativos à nação como um todo. Seu estado de origem, quando da avaliação das políticas pelas quais lutam, é apenas mais uma variável, a atrapalhar ou ajudar o desempenho agregado do país.

Assim, o que nos interessou no artigo foi constatar que a participação política do Rio de Janeiro no governo federal foi praticamente nula a partir de meados da década de 1970 do século passado até boa parte do período relativo à transição e consolidação democrática. Já no começo do século XXI, a balança continuou a oscilar, agora em bases democráticas, para o lado do governo central, forçando cariocas e fluminenses a ter que importar a política deste para terem novamente um papel político nacional relevante.

De maneira complementar, o esvaziamento econômico por que passou o Rio desde 1950 e a transferência dos ativos administrativos da capital para Brasília em 1960 também devem ser considerados fatores relevantes no declínio político da região, uma vez que dinamismo econômico e poder político costumam andar de mãos dadas. Porém, a perda de influência política no âmbito nacional decorrente de esforços bem-sucedidos do regime militar certamente contribuiu para acentuar o declínio econômico. Além disso, a implantação do brizolismo no estado a partir de 1983 acabou por ampliar mais ainda o fosso entre o Rio de Janeiro e o governo federal, gerando um ciclo vicioso entre decadência econômica e desentrosamento político, agravado pela crise inflacionária da década de 1980 e do começo da década seguinte.

Ao que tudo indica, este ciclo parece ter chegado ao fim a partir de 2007, quando o estado e o Executivo federal voltaram a se alinhar politicamente, criando um ciclo virtuoso entre cooperação intergovernamental e revitalização econômica. A questão-chave agora é saber se a retomada da relevância política do Rio tornou-se um valor e desiderato de suas elites, isto é, com tendência a se tornar meta permanente das próximas gerações de políticos do estado. Ainda está por ser comprovado se o atual ciclo nada mais seria do que resultado da astúcia dos últimos governantes, passageiro, portanto, tanto quanto o são as pessoas, ao invés das instituições e práticas governamentais.

(Recebido para publicação em março de 2013)

(Reapresentado em julho de 2013)

(Aprovado para publicação em agosto de 2013)

DADOS - Revista de Ciências Sociais, Rio de Janeiro, vol. 56, nº 3, 2013 


\section{Octavio Amorim Neto e Fabiano Santos}

\section{NOTAS}

1. A distinção entre ministros que possuem origem estadual relevante e os que não o possuem segue, em boa medida, a adotada por Santos (1971) em sua análise sobre o perfil dos governadores nomeados pelos militares em 1970, em contraposição à geração anterior, de 1966, ainda escolhidos pelo meio do voto. O importante para nós, assim como para Santos, consiste na via de acesso ao cargo, se por conta de seu currículo como profissional ou como político.

2. Convém enfatizar que dois importantes ministros de Geisel, Mário Henrique Simonsen, da Fazenda, e Antônio Francisco Azeredo da Silveira, das Relações Exteriores, eram naturais do Rio, mas suas nomeações não tiveram a ver com sua origem carioca.

3. Para uma excelente discussão das diversas motivações e da longa história da fusão, ver Ferreira e Grynszpan (2000).

4. Na verdade, o desempenho do PFL no Rio de Janeiro a partir de meados da década de 1990 acompanhou a trajetória de um político específico, Cesar Maia. Oriundo das hostes brizolistas, Maia se transferiu para o eleitorado conservador em 1992, logrando conquistar a prefeitura da capital do estado três vezes. Conflitos com parceiros nacionais, como o PSDB, além de acirradas disputas internas pela liderança do partido, acabaram por não institucionalizar o DEM como a opção conservadora no Rio como fora o caso da UDN.

5. Amorim Neto e Simonassi (2013) mostram que, entre 1985 e 2004, níveis mais elevados de transferência de recursos per capita do governo federal para os governos estaduais estão associados à composição partidária-estadual das coalizões governativas .

6. Sobre as facções do MDB no Rio de Janeiro, ver o estudo clássico de Eli Diniz (1982).

7. Sobre o "brizolismo" na política carioca, o estudo de referência é Sé (1999).

8. Segundo Arretche (2012:145-171), a centralização a que nos referimos fortaleceu os municípios sobretudo como executores de políticas federais. Quanto aos estados, os mecanismos que contribuíram para o seu relativo enfraquecimento foram a reestruturação das dívidas estaduais e as restrições orçamentárias impostas pela Lei de Responsabilidade Fiscal.

9. De acordo com os dados de Azzone para 1939-2010, dos outros quatro grandes estados (BA, PE, PR e RS), apenas Pernambuco experimentou um declínio econômico da magnitude verificada para o Rio: de um pico de 4,5 em 1939 para 2,3\% em 2004.

10. Análises clássicas sobre a evolução do sistema partidário durante o período 1946-1964, como são os casos de Soares (1973) e Souza (1976), de alguma forma ecoam a visão dualista segundo a qual existiriam duas formas distintas de se fazer política no Brasil: uma ideológica, autenticamente representativa, e outra, oligárquica, patrimonialista, em algumas versões, estadocêntrica. Tais "estilos" de se praticar a política, ademais, seriam bem localizados geograficamente. Nossa visão corresponde mais à linha adotada por Lima Jr. (1983), em estudo igualmente importante, de compreender as variações políticas na Federação brasileira segundo o que chamou de "racionalidade contextual". Nesta perspectiva, não haveria espaços geográficos mais claramente representativos, mais ou menos ideológicos. As estratégias dos partidos variariam de acordo com o contexto da disputa pelo voto, isto é, os principais adversários em âmbito estadual e os níveis de disputa, se estadual ou nacional. Neste sentido, clientelismo, patrimonialismo e ideologia conviveriam lado a lado no inte- 
rior de uma mesma unidade da Federação, sendo a intensidade de seu uso função de tais variáveis.

11. O termo populismo possui diversas definições, dependendo do autor, país e contexto histórico em que é utilizado. No Brasil, é muito comum uma acepção pejorativa do termo, acepção oriunda quase sempre de uma visão da política como epifenômeno. Tome-se, por exemplo, o conhecido estudo de Weffort (1978), em que diversos tipos de políticos populistas são definidos e suas bases sociais, identificadas. Contextos sociais subdesenvolvidos, nesta visão, levariam à produção de líderes políticos ruins. Contextos desenvolvidos gerariam lideranças modernas. A política é vista como destituída de poder de agência, ou, como diria Santos (1986), um “balé metafórico da economia", incapaz de, através de mecanismos como o voto e partidos, modificar a ecologia social e impulsionar mudanças modernizadoras. 


\section{Octavio Amorim Neto e Fabiano Santos}

\section{REFERÊNCIAS BIBLIOGRÁFICAS}

ABRANCHES, Sérgio H. Hudson de. (1988), "Presidencialismo de Coalizão: O Dilema Institucional Brasileiro". Dados, vol. 31, no 1, pp. 5-38.

ABREU, Alzira Alves de et al (orgs.). (2001), Dicionário Histórico-Biográfico Brasileiro pós-1930. Rio de Janeiro, Editora FGV.

AMORIM NETO, Octavio. (1991), Formação Ministerial em Sistemas Presidencialistas Multipartidários: O Caso Brasileiro (1946-1964). Dissertação de Mestrado, Instituto Universitário de Pesquisas do Rio de Janeiro (IUPERJ).

. (2007), “Algumas Conseqüências Políticas de Lula: Novos Padrões de Formação e Recrutamento Ministerial, Controle de Agenda e Produção Legislativa", in J. Nicolau e T. J. Power (orgs.), Instituições Representativas no Brasil: Balanço e Reformas. Belo Horizonte, Editora UFMG.

e SANTOS, Fabiano. (2003), “O Segredo Ineficiente Revisto: O que Propõem e Aprovam os Deputados Brasileiros". Dados, vol. 46, no 4, pp. 661-698.

AMORIM NETO, Octavio e SIMONASSI, Andrei. (2013), “Bases Políticas das Transferências Intergovernamentais no Brasil (1985-2004)". Revista de Economia Política, vol. 33, no 4, pp. 704-725.

ARRETCHE, Marta. (2012), Democracia, Federalismo e Centralização no Brasil. Rio de Janeiro, Editora FGV.

CENTENO, Miguel A. e SILVA, Patrício. (1998), "The Politics of Expertise in Latin America: Introduction", in M. A. Centeno e P. Silva (orgs.), The Politics of Expertise in Latin America. New York, St. Martin's Press.

DIAS, José Luciano. (2000), "Partidos e Eleições no Rio de Janeiro - 1974-94", in M. de Moraes Ferreira (org.), Rio de Janeiro: Uma Cidade na História. Rio de Janeiro, Editora FGV.

DINIZ, Eli. (1982), Voto e Maquina Política: Patronagem e Clientelismo no Rio de Janeiro. Rio de Janeiro, Paz e Terra.

FAORO, Raymundo. (1958), Os Donos do Poder: Formação do Patronato Político Brasileiro. Porto Alegre, Editora Globo.

FERREIRA, Marieta de Moraes (org.). (2000), Rio de Janeiro: Uma Cidade na História. Rio de Janeiro, Editora FGV.

e GRYNSZPAN, Mario. (2000), “A Volta do Filho Pródigo ao Lar Paterno? A Fusão do Rio de Janeiro", in M. de Moraes Ferreira (org.), Rio de Janeiro: Uma Cidade na História. Rio de Janeiro, Editora FGV.

FIGUEIREDO, Argelina C. e LIMONGI, Fernando. (2007), “Instituições Políticas e Governabilidade: Desempenho do Governo e Apoio Legislativo na Democracia Brasileira", in C. Ranulfo Melo e M. A. Saez (orgs.), A Democracia Brasileira: Balanço e Perspectivas para o Século XXI. Belo Horizonte, Editora UFMG.

FREIRE, Américo; SARMENTO, Carlos Eduardo e MOTTA, Marly Silva (orgs.). (2001), Um Estado em Questão: Os 25 Anos do Rio de Janeiro. Rio de Janeiro, Editora FGV. 
LESSA, Carlos. (2000), O Rio de Todos os Brasis: Uma Reflexão em Busca de Auto-Estima. Rio de Janeiro, Record.

LIMA JÚNIOR, Olavo Brasil de. (1983), Os Partidos Políticos Brasileiros: A Experiência Federal e Regional (1945-1964). Rio de Janeiro, Graal.

; SANTOS, Fabiano e AMORIM NETO, Octavio. (1987), “Fragmentação Eleitoral e Radicalização Ideológica no Rio de Janeiro: Impacto da Política Estadual na Política Nacional (1945-1964)". Dados, vol. 30, no 2, pp. 167-186.

LOVE, Joseph. (1971), Rio Grande do Sul and Brazilian Regionalism, 1882-1930. Stanford, Stanford University Press.

(1980), São Paulo in the Brazilian Federation, 1889-1937. Stanford, Stanford University Press.

MOTTA, Marly Silva da. (2001), Rio de Janeiro: De Cidade-Capital a Estado da Guanabara. Rio de Janeiro, Editora FGV.

OSÓRIO, Mauro. (2005), Rio Nacional, Rio Local: Mitos e Visões da Crise Carioca e Fluminense. Rio de Janeiro, Editora Senac Rio.

SANTOS, Fabiano. (2003), O Poder Legislativo no Presidencialismo de Coalizão. Belo Horizonte, Editora UFMG.

(2007), "República de 46: Separação de Poderes e Política Alocativa”, in C. Ranulfo Melo e M. A. Saez (orgs.), A Democracia Brasileira: Balanço e Perspectivas para o Século XXI. Belo Horizonte, Editora UFMG.

SANTOS, Wanderley Guilherme dos. (1971), “Governadores-Políticos, GovernadoresTécnicos, Governadores-Militares". Dados, vol. 8, pp. 123-128.

(1986), Sessenta e Quatro: Anatomia da Crise. São Paulo, Vértice.

SCHWARTZMAN, Simon. (1982), Bases do Autoritarismo Brasileiro. Brasília, Editora da Universidade de Brasília.

SÉ, João Trajano Sento. (1999), Brizolismo: Estetização da Política e Carisma. Rio de Janeiro, Espaço e Tempo/FGV.

SKIDMORE, Thomas E. (1988), The Politics of Military Rule in Brazil, 1964-85. New York, Oxford University Press.

SOARES, Gláucio Ary Dillon. (1973), Sociedade e Política no Brasil. Rio de Janeiro, Difel.

SOUZA, Maria do Carmo Campello e. (1976), Estado e Partidos Políticos no Brasil. São Paulo, Alfa-Ômega.

WEFFORT, Francisco C. (1978), O Populismo na Política Brasileira. Rio de Janeiro, Paz e Terra.

WIRTH, John D. (1977), Minas Gerais and the Brazilian Federation, 1889-1937. Stanford, California University Press.

DADOS - Revista de Ciências Sociais, Rio de Janeiro, vol. 56, nº 3, 2013 


\section{Octavio Amorim Neto e Fabiano Santos}

\section{ABSTRACT \\ Rio de Janeiro and the National State (1946-2010)}

This article argues that the political heft of a specific state (Rio de Janeiro) within the Federative Republic of Brazil has to do with how state party politics relates to the national party politics. The article assesses the decline in Rio's role in national politics before and after transfer of the national capital to Brasilia in 1960 and the fusion of Guanabara with the former state of Rio de Janeiro in 1975. The article draws on previously unpublished data and proposes two hypotheses: (1) the share of cabinet posts held by politicians from Rio de Janeiro is largely a function of the state's relative weight in the main governing parties' delegations in the Chamber of Deputies and (2) that the strengthening of the Federal government since the promulgation of the 1988 Constitution prompted Rio to adjust to the party alliances forged by the various Presidents, thereby contributing to a relatively recovery of the state's national political influence in the first decade of the $21^{\text {st }}$ century. Finally, the article provides a normative reflection on the consequences, for Brazil, of Rio de Janeiro's political and economic decline.

Key words: federalism and political institutions; state politics; Rio de Janeiro

\section{RÉSUMÉ}

Rio de Janeiro et l'État National (1946-2010)

Dans cet article, on montre que la trajectoire politique d'un État brésilien particulier, celui de Rio de Janeiro, au sein d'une république fédérative, adopte la façon dont les contours plus généraux de sa politique sont reliés au cadre politique et à celui des partis, à l'échelon national. On évalue le déclin du rôle de l'état dans la politique nationale avant et après le transfert de la capitale à Brasília en 1960 et à partir de la fusion de l'État de Guanabara avec l'ancien État de Rio de Janeiro en 1975, par le biais de vérifications empiriques inédites, alliées à deux hypothèses: (1) la participation d'hommes politiques de Rio dans les cabinets présidentiels est, pour une large part, fonction du poids relatif de l'État dans les groupes de députés fédéraux des principaux partis présents au gouvernement; et 2) le renforcement du gouvernement central depuis la Constitution de 1988 a stimulé Rio à s'ajuster aux alliances entre partis passées par les présidents, ce qui a contribué à un relatif rétablissement de l'influence nationale de l'État dans les dix premières années du XXI ${ }^{\mathrm{e}}$ siècle. On arrive, enfin, à une réflexion de type normatif concernant les conséquences, pour le Brésil, du déclin politique et économique de l'État.

Mots-clés: fédéralisme et institutions politiques; polítique de l'État; Rio de Janeiro 